\title{
Development of activity of daily living modules based on behavioral approaches for moderate intellectual disability
}

\author{
Noorita Dwi Sulistyaningrum *, Mumpuniarti Mumpuniarti, Nurkhamid Nurkhamid \\ Universitas Negeri Yogyakarta. Jalan Colombo No. 1, Karangmalang, Yogyakarta 55281, Indonesia \\ * Corresponding Author. E-mail: noorita.dwi2016@student.uny.ac.id
}

\begin{abstract}
Moderate intellectual disability requires a specific behavioral approach of learning Activity of Daily Living (ADL). This study aims to develop an appropriate and effective ADL module for moderate category intellectual disabilities in a special program instruction based on behavioral approaches. This research is a Research and Development (R\&D) using the Dick and Carey development model. The Dick and Carey development model consists of 10 steps of development, namely identifying needs in setting goals, analyzing learning, analyzing learners and context, developing learning objectives, developing assessment instruments, developing learning strategies, developing and selecting learning materials, designing and implementing formative evaluations, improving learning, designing and conducting the summative assessment. The module was implemented in the Special School of PGRI Sentolo and the Special School of Ma'arif Bantul through individual trials involving one subject, a small group trial involving six subjects, and a field test involving 15 subjects. Data collection was carried out using interviews, observations, questionnaires, and performance tests. The results of the study are that the ADL module is feasible and effective to use. The module was designed according to a behavioral approach, including: the objectives were arranged from simple to complex, the presentation of the material was based on task analysis, verbal positive reinforcement was presented by the flap lift, and rewards are provided as star stickers available in the module.
\end{abstract}

Keywords: activity of daily living learning module, moderate category intellectual disability

How to Cite: Sulistyaningrum, N., Mumpuniarti, M., \& Nurkhamid, N. (2021). Development of activity of daily living modules based on behavioral approaches for moderate intellectual disability. Jurnal Prima Edukasia, 9(1), 1-15. doi:https://doi.org/10.21831/jpe.v9i1.32857

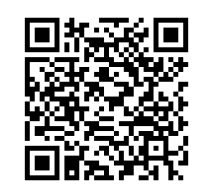

\section{Introduction}

Children with intellectual disability experience barriers in thinking make them experiencing problems in learning. Learning problems with intellectual disabilities include, among others, unable to sort the steps in carrying out the activity of daily living (ADL) skills, subsequently the technical way of doing movements for self-development, such as self-building. The condition of children with intellectual disabilities affects the cognitive ability, learning and adaptive skills in their daily lives. These adaptive skills as well as conceptual adaptive skills, social and practice (Harris, 2010, p. 5). Children with intellectual disabilities can be classified into several categories, namely mild, moderate and severe. Children who often need help from others but yet still be given functional academic learning and self-development skills, namely moderate or moderate intellectual disability. Based on Diaz (2020), that children with intellectual disability in moderate category are less likely to do regular physical activity and have the lowest probability among all subgroups of children with other developmental barriers.

Children with intellectual disability in moderate category have IQ capability around 35-50 so they really need special treatments in both functional and non-academic fields (Hallahan et al., 2018, p. 149). On School programs, children with intellectual disability moderate category need to be given special learning program, namely self-development. Based on the research that had done by Dewi et al. (2017), that the existence of self-development learning in schools, which is given by expert teachers on their fields and use relevant strategies, methods and guidelines, children can carry out their daily activities independently, at least for daily activities and the simplest one every day.

Self-development learning that is given for children will help them assist themselves. Self-help is a skill that has basic self-care but does not attain self-adjustment so it will always require some levels of supervision (Baroff \& Olley, 2014, p. 58). The function of self-development activities can be 
Jurnal Prima Edukasia, 9 (1), 2021 - 2

Noorita Dwi Sulistyaningrum, Mumpuniarti Mumpuniarti, Nurkhamid Nurkhamid

described as follows (1) developing basic or important skills to maintain personal needs, (2) completing basic tasks efficiently in social contact so that they can be accepted in their living environment, and (3) increase independence (Bilqis, 2014, p. 35; Sudarsini, 2019, p. 67). Based on these functions, it can be seen that mastering self-development skills can help children to adapt in the surrounding environment because it is related to the main activities for their independence. Research by Udonwa et al. (2015, p. 21), stated that there is a significant relationship between intellectual disability and deficits in daily living skills such as toilet use, dressing, meal, personal hygiene, etc.

Self-development learning given to children can include many activities of daily living activities. Daily activities comprise of bathing, dressing, eating, caring, getting in or out of bed, walking in the house, walking outside house, using toilet, preparing meal at house (Albert, 2014, p. 93; Steinmetz, 2013 , p. 218). These activities are generally carried out by everyone so that the moderate category of intellectual disability children also needs to be given the learning of these skills. With learning that supports the needs of children, they will be able to live independently even though there is still supervision from parents and others. Based on Dewi et al. (2017) that the existence of self-development learning in schools, aiming for very simple skills such as self-care consisting of various skills.

Based on observations in SLB PGRI Sentolo and SLB Ma arif Bantul, children with moderate intellectual disabilities still have difficulty wearing and removing clothes. These difficulties include wearing and removing button-down shirts, wearing pants, clothing accessories and clothes as needed. In addition, self-development learning is still limited in the use of modules. Although self-development skills will be more in practical activities, but the existence of modules or self-development books as a reference in learning is very necessary. Furthermore, it is also difficult to find self-development teaching materials, which show the steps for self-development in more details so that it can be understood by children. Teaching materials such as existing self-development modules are still used as teachers' guidelines in providing material that cannot be used by children. Therefore, there is a need for teaching materials that can be directly used by children. Teaching materials can help children practice self-building and can be done continuously. The results of the research by Adnyani et al. (2015), show that: (1) there is an effect of the drill method on the learning motivation of class I SLB.C1 Negeri Denpasar in the academic year 2014/2015, (2) there is an effect of the drill method on self-care ability of class I SLB.C1 Negeri Denpasar in the academic year 2014/2015. So this continuous exercise is very convenient for children with moderate intellectual disabilities. In addition, based on research Garrels (2017, p. 505), the need for teacher training to focus more on how to teach students with intellectual disabilities the skills needed to become independent learners and independent adults.

Based on the research results of Adisty et al. (2014, p. 164), that researchers found problems in learning, namely the motivation of children is still low in following the learning theme "Self" which leads to self-development activities. Moreover, it is also related to the activeness of children in participating in learning, namely children tend to be passive, pay less attention to explanations from the teacher, often play individually in class and indolent to work on assignments given by the teacher. Based on these conditions, there needs to be an effort to overcome the problems in self-development learning. Therefore, researchers developed a learning module.

The activity of daily living learning module was developed through a behavioral approach. The behavioral approach is designed to help change maladaptive behavior (Adi, 2013, p. 29). Thus, this approach helps to change the child's behavior that is inappropriate or deviates from expectations into the expected behavior. Behavioral approach can be applied because it emphasizes learning through aspects that can be seen so that it relates to changes in behavior that occur. Stark et al. (2012, p. 171) stated that there is a successful behaviour approach in the treatment of a number of behavioural disorders which can represent an adequate approach for the effective management of various disorders in children with intellectual disabilities. From this opinion, it can be seen that the behavioral approach can handle problems faced by children with intellectual disabilities. Based on the research by Boesch et al. (2015, p. 323) show that the behavioral approach which is given can solve problems in children with autism and it can also be applied to children with intellectual disabilities. Teaching will be more effective regard to the principles of behavioral theory, namely (1) the teacher provides material in smaller steps or in the form of small units and is arranged in a logical order so that learners can easily learn it, (2) students respond actively rather than just listening passively, (3) the teacher provides immediate feedback after receiving responses from learners so that learners can find out whether the response given is correct or not and (4) students learn the material given according to their own rhythm, (5) whenever the learner 
Jurnal Prima Edukasia, 9 (1), 2021 - 3

Noorita Dwi Sulistyaningrum, Mumpuniarti Mumpuniarti, Nurkhamid Nurkhamid

gives the correct response, it is necessary to be given reinforcement, (6) emphasizes the formation of habits through exercise and repetition (Schunk, 2012, p. 142; Thobroni, 2011, pp. 65-88). Therefore, this behavioral approach is suitable if applied to children with intellectual disabilities because the principles are in accordance with the obstacles experienced by children with intellectual disabilities.

The development of modules in this study aims to generate a product in the form of a module that can be used for learning special self-development programs for moderate intellectual disabilities at the elementary school level. Modules can help children to have motivation and enthusiasm for learning. Research by Setyorini and Izzaty (2016) shows that there is a significant difference in learning motivation between students who take learning with learning tools and those who do not use development learning tools. The results of this study are reciprocal with (Ingwarni, 2018) that there is a significant difference in learning motivation between students who use learning modules and students who do not use learning modules. This module is a module that can be used directly by children while still having guidance from the teacher. The module was tested for its feasibility by several experts and field tested by teachers and children.

Thus, based on the description above the objectives of this study are a) to produce an ADL (activity of daily living) learning module based on a behavioral approach for a special program for moderate category intellectual disabilities to assist in learning to build self-development in wearing and taking off clothes and b) knowing the feasibility of the module ADL learning for children with moderate intellectual disabilities in the learning of self-development to wear and take off clothes.

\section{Method}

Development Model

The development model used is to adapt the Dick and Carey development model. The Dick and Carrey development model was chosen because it elaborates development steps more detailed. Dick et al. (2015) stated that the development model is a learning system by developing components that need to be done in designing learning activities that ensure that the material developed for all types of teaching is responsive to the needs of the recipients and effective in achieving the aimed learning outcomes.

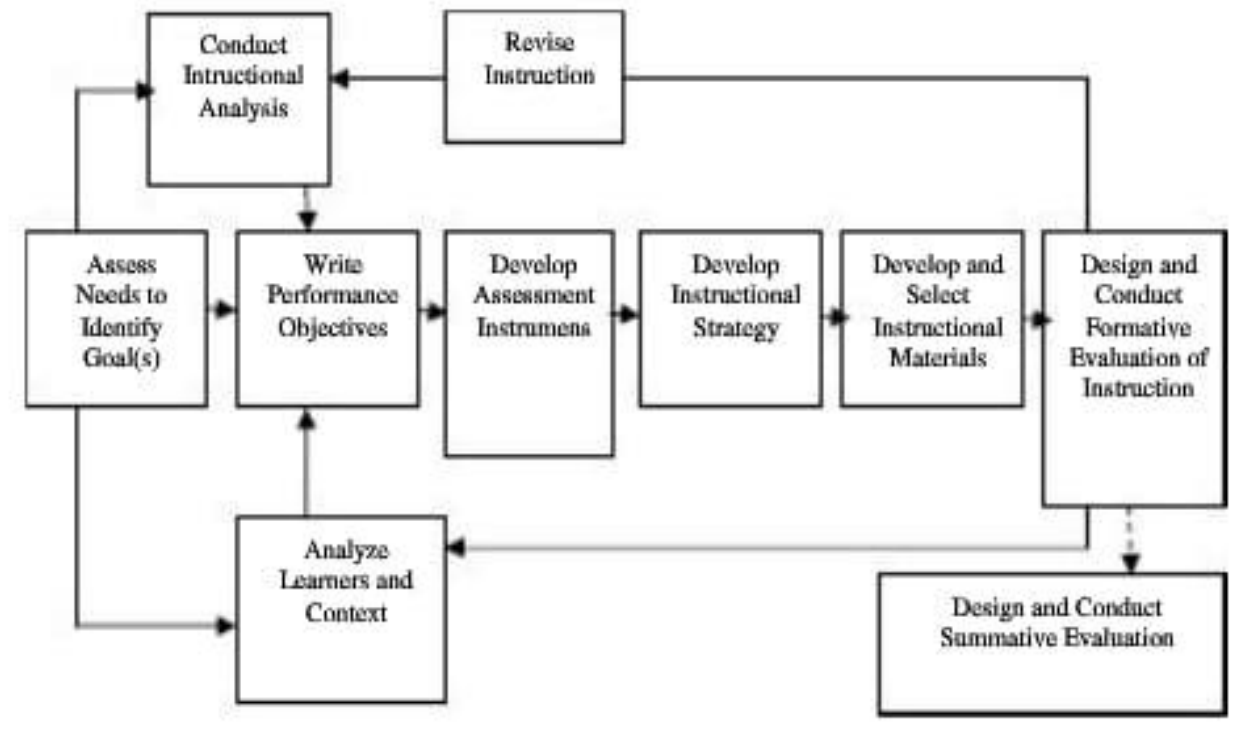

Figure 1. The Development model by Dick \& Carey (Modified by Dick et al. (2015))

Development research according to Dick et al. (2015, pp. 6-8) has 10 steps that can be done, namely (1) identify instructional goals (identify needs in determining goals), (2) conduct instructional analysis (conduct analysis in learning), (3) analyze learners and contexts (analyze related learners and context), (4) write performance objectives (write down learning objectives), (5) develop assessment instruments (develop assessment instruments), (6) develop instructional strategies (develop learning strategies), (7) develop and select instructional materials (develop and select learning materials), (8) design and conduct formative evaluation of instruction (design and implement formative evaluation), (9) revise instruction (improve learning), (10) design and conduct summative evaluation (design and 
Jurnal Prima Edukasia, 9 (1), 2021 - 4

Noorita Dwi Sulistyaningrum, Mumpuniarti Mumpuniarti, Nurkhamid Nurkhamid

conduct summative evaluation). The development model according to Dick \& Carey can be presented in the Figure 1.

There are nine stages of Dick \& Carey development carried out by researchers. The Figure 2 is the development procedure in this research, as follows

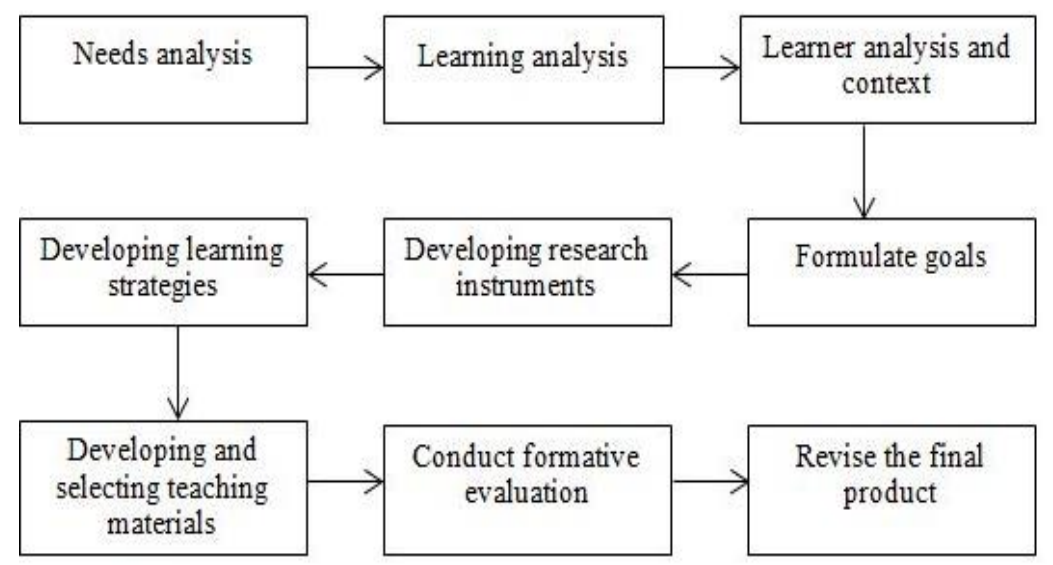

Figure 2. Stages Research Development

The Design of Trial Product

On the trial design stage, the activity of daily living (ADL) module is validated by media experts and material experts before conducting the trial. Assessments and suggestions from experts' team are used to improve the product and then it can be tested. The trial was accomplished three times which included individual trials, small group trials and field trials. The trial subjects in this development research were children with moderate intellectual disabilities. Individual trials involving one subject with intellectual disabilities, small group trials involving six subjects and field trials involving 15 subjects. Each trial was also supported by teacher responses. The trial subjects in this research were children with moderate categories of intellectual disabilities in class II and III SDLB. The place of research was accomplished in SLB PGRI Sentolo and SLB Ma'arif Bantul.

\section{Instrument of Collecting Data}

The data collection techniques used were adjusted to the data disclosed starting from preliminary studies, module development and product trials. The techniques of collecting data used comprise of interviews, observation, documentation, document analysis, and questionnaires. Interviews were conducted with teachers; observations were made during self-development learning activities so that the implementation and abilities of students with intellectual disabilities were known. Documentation was conducted to collect evidence, both documents and photos of self-development learning. Document analysis was accomplished by analyzing curriculum documents related to self-development learning and questionnaires were given to students and teachers to determine the feasibility of the ADL module.

\section{Data Analysis Technique}

The technique of data analysis was conducted when analyzing the results of the study of needs and feasibility of the module. Data analysis technique in the study of needs was conducted with a qualitative descriptive analysis. Data analysis qualitative descriptive includes data reduction, data display and conclusion drawing/verification (Sugiyono, 2010).

Table 1. Conversion of Quantitative Data to Qualitative Data on a Scale of 5

\begin{tabular}{ccc}
\hline Average Score Range & Predicate & Category \\
\hline $\bar{x}>\mathrm{M}_{\mathrm{i}}+1,8 \mathrm{SB}_{\mathrm{i}}$ & $\mathrm{A}$ & Very Good \\
$\mathrm{M}_{\mathrm{i}}+0,6 \mathrm{SB}_{\mathrm{i}}<\overline{\mathrm{x}} \leq \mathrm{M}_{\mathrm{i}}+1,8 \mathrm{SB}_{\mathrm{i}}$ & $\mathrm{B}$ & Good \\
$\mathrm{M}_{\mathrm{i}}-0,6 \mathrm{SB}_{\mathrm{i}}<\overline{\mathrm{x}} \leq \mathrm{M}_{\mathrm{i}}+0,6 \mathrm{SB}_{\mathrm{i}}$ & $\mathrm{C}$ & Moderate \\
$\mathrm{M}_{\mathrm{i}}-1,8 \mathrm{SB}_{\mathrm{i}}<\overline{\mathrm{x}} \leq \mathrm{M}_{\mathrm{i}}-0,6 \mathrm{SB}_{\mathrm{i}}$ & $\mathrm{D}$ & Less \\
$\overline{\mathrm{x}} \leq \mathrm{M}_{\mathrm{i}}-1,8 \mathrm{SB}_{\mathrm{i}}$ & $\mathrm{E}$ & Poor \\
\hline
\end{tabular}


Jurnal Prima Edukasia, 9 (1), 2021 - 5

Noorita Dwi Sulistyaningrum, Mumpuniarti Mumpuniarti, Nurkhamid Nurkhamid

The data analysis technique used to deter-mine the feasibility of the module is a quantitative descriptive analysis technique, but there is still a qualitative presentation. The data analyzed included media feasibility data from media experts and material experts as well as three field trials (individual trials, small group trials and field tests). The Table 1 shows the conversion of quantitative data to qualitative data on a scale of 5 .

\section{Result and Discussion}

The needs analysis stage in determining this goal is accomplished through observation, interviews and document analysis. Needs analysis activities were conducted at SLB PGRI Sentolo and SLB Ma'arif Bantul. Based on the results of observations, interviews and document analysis, learning materials are determined by perceiving at the curriculum and students' abilities. Students have difficulty wearing and removing clothes. In the curriculum, the competence of wearing and removing clothes, in which there are several indicators that can be taught to students, starting from wearing t-shirts, button-down shirts to wearing clothes as needed. In the assessment of the ability to perform ADL, the teacher uses assessments (4) able to be independently, (3) capable with a little guidance, (2) capable with a lot of guidance, (1) not yet able. On average, students get capable results with little or much guidance. Moreover, there are students who are in the incapable category when wearing button-down clothes and wearing strappy shoes.

The provision of material was carried out by the teacher explaining the ADL activities that going to be studied, then demonstrated which were followed by students. Children's responses when learning related to communication are still lacking because most of the students' responses are in mimicking activities. The enthusiasm of students is also still lacking in the implementation of learning. The implementation of ADL learning is accomplished twice a week with 4 hours of lessons (@ 35 minutes) and the material is given according to the conditions of students and repeated on the same material. The media used is in accordance with the self-development activities that are being taught, for example, the material is wearing clothes, so there are clothes that can be used for practice. However, there are no teaching materials such as modules or self-help books during the learning process.

This development research aims to produce an activity of daily living (ADL) module based on a behavioral approach for moderate intellectual disabilities that is proper and used when learning special programs. The activity of daily living module is a teaching material that can be directly used by students with teacher guidance and the material is presented in the form of images according to task analysis. The material in the module is focused on wearing and removing clothes so that it can help students from wearing t-shirts to choosing and wearing clothes as needed. In addition, the module also contains positive verbal reinforcement presented by lift the flap and reward in the form of star stickers.

Product validation is conducted by material experts and media experts. The results of the assessment of the material and media experts are calculated on each aspect, indicator, as well as the total score for each aspect and as a whole. If the score has been obtained, it will be converted related to product feasibility by material and media experts. The Figure 3 is the results of the assessment from material experts.

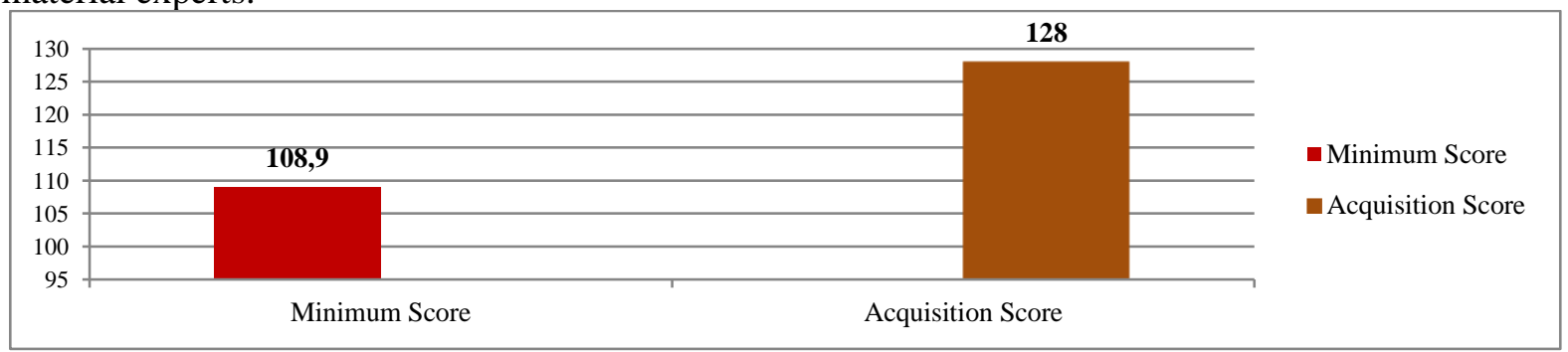

Figure 3. Results of the Material Expert Product Assessment

Based on the bar (Figure 3), it can be seen that the total score of the material expert's assessment regarding content feasibility, linguistic feasibility, presentation feasibility and behavioral approaches got a score of 128 with predicate B and category "good". While the minimum score is 108.8, so it has exceeded the minimum limit so that it can be said the product is suitable for to be used. Thus, it can be concluded that the score obtained is greater than the minimum score, so this product can be used by students with moderate intellectual disabilities. As for the revision results from material experts, namely

Copyright (C) 2021, Jurnal Prima Edukasia, ISSN 2338-4743 (print), ISSN 2460-9927 (online) 
Jurnal Prima Edukasia, 9 (1), 2021 - 6

Noorita Dwi Sulistyaningrum, Mumpuniarti Mumpuniarti, Nurkhamid Nurkhamid

the material for wearing and removing clothes needs to be completed again such as wearing pants and skirts, these materials are focused again for grade II or III SDLB because if it is applied to grade 1 SDLB will be too high in difficulty and motivation for the product can be add more.

Product assessment by media experts includes appearance feasibility, linguistic feasibility, presentation feasibility and behavioral approaches in the module. The Figure 4 is showing the minimum score and scores obtained from media experts, namely:

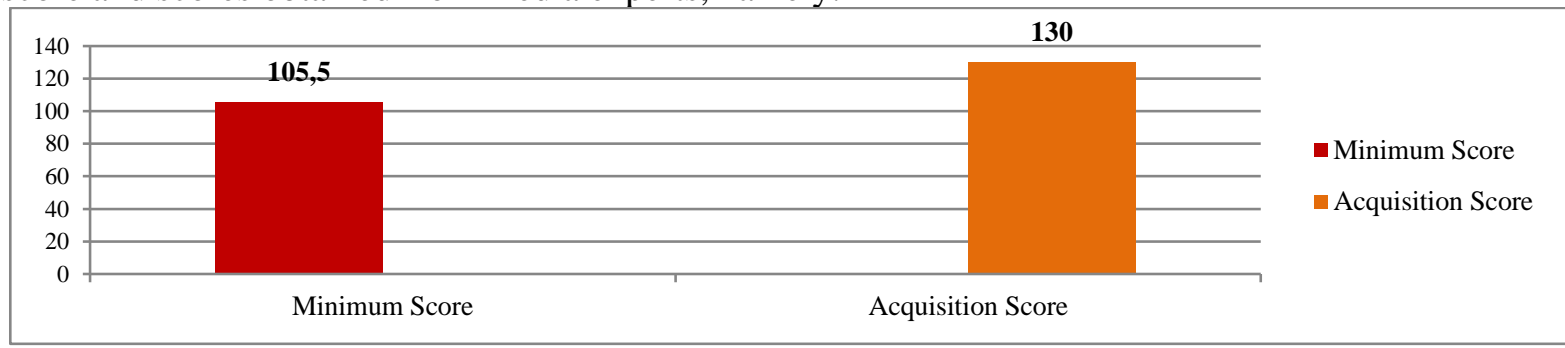

Figure 4. Media Expert Product Assessment Results

The Figure 4 shows that the total score for the ADL module assessment by media experts is higher than the minimum score. The total score obtained is 130 with the predicate B and category "Good" while the minimum score is 105.5 so it is obvious that the scores obtained from media experts can exceed the minimum score. Thus, it can be concluded that the activity of daily living module based on the behavioral approach for mental retardation in the moderate category is feasible to be used. The following suggestions must be improved, namely: (1) material organization must be made clear or structured and use communicative language, (2) the layout is more systematic because the image layout is less clear in relation to the scope of the material, (3) it is packaged in a learning module because it does not describe the learning module, (4) complete with a user guide.

Furthermore, the results of product trials include individual trials, small group trials and field trials. In the individual trial, it was conducted on 1 subject, namely children with moderate intellectual disabilities at the SDLB level. Individual trials were conducted at SLB PGRI Sentolo involving 1 child and 2 teachers. The Figure 5 is the total score responses of teachers I and II from the results of the trials conducted:

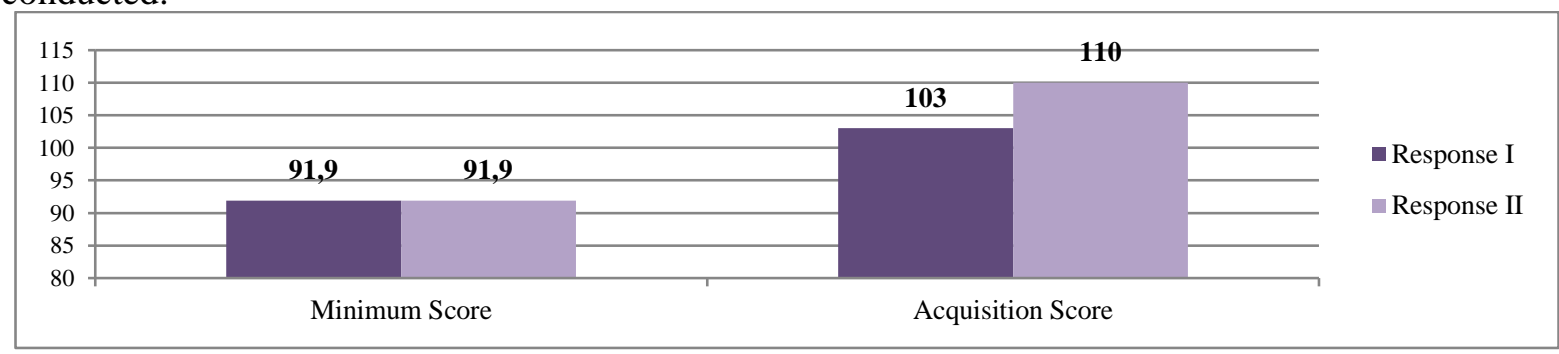

Figure 5. Results of Teacher I and II Responses on Individual Trials

The Figure 5 shows that the total teacher responses to the ADL module are in the "good" category. The minimum score in the diagram is 91.9, while the total score obtained in teacher I's response is 103 and teacher II's response is 110 so that it has exceeded the minimum score. However, improvements are still needed according to suggestions from teachers 1 and II. Furthermore, the results of children's responses in individual trials can be described in the Figure 6.

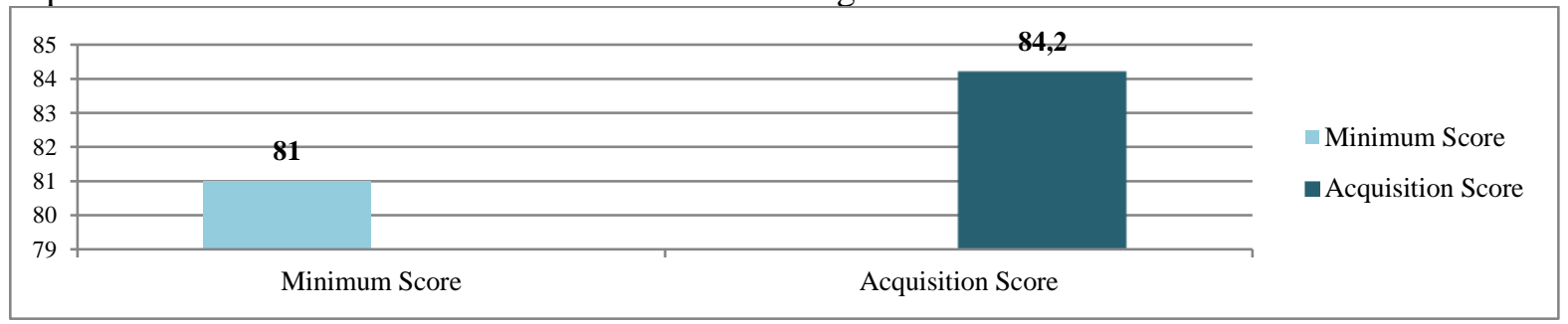

Figure 6. Results of Children's Response Scores in Individual Trials

Based on the Figure 6, it can be seen that the acquisition score obtained by the child is 84.2. While the minimum score is 81 , so the score obtained by children in individual trials has exceeded the 
minimum score. Based on children's responses, that the activity of daily living module is interesting, easy to understand and can motivate children to learn.

In small group trials conducted at SLB PGRI Sentolo on students with moderate category intellectual disabilities, there were 6 children who had not yet become the subject of individual trials and involved 3 teacher responses. The Figure 7 is the total score from the teacher response questionnaire:

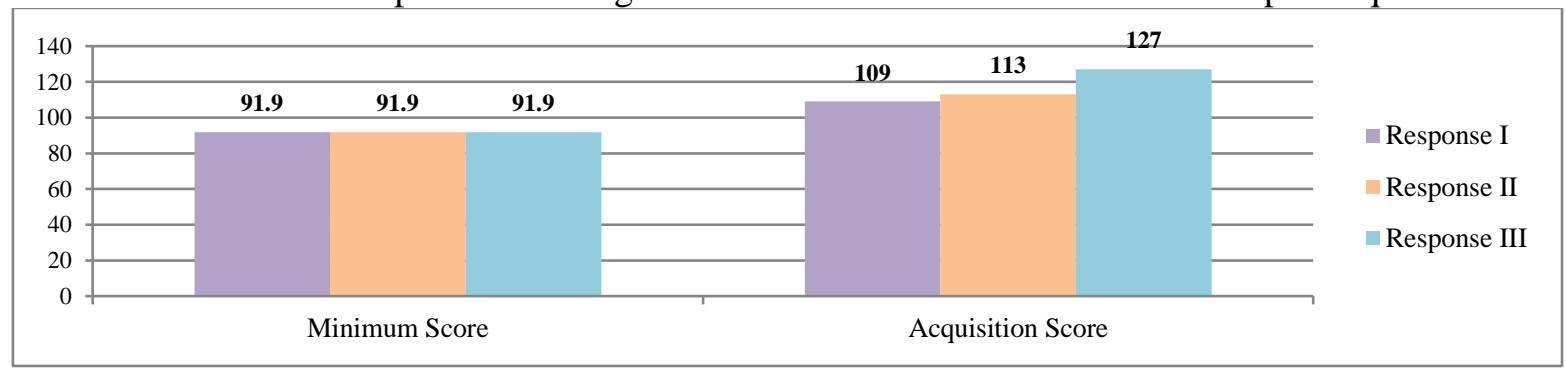

Figure 7. Results of Teacher Responses in Small Group Trials

Based on Figure 7 it can be explained that the average total score of teacher responses in small group trials to the activity of daily living module can be said to be "very good". The teacher's response can exceed the minimum score of 91.9. Furthermore, for the results of the child's response score, it can be seen in the Figure 8.

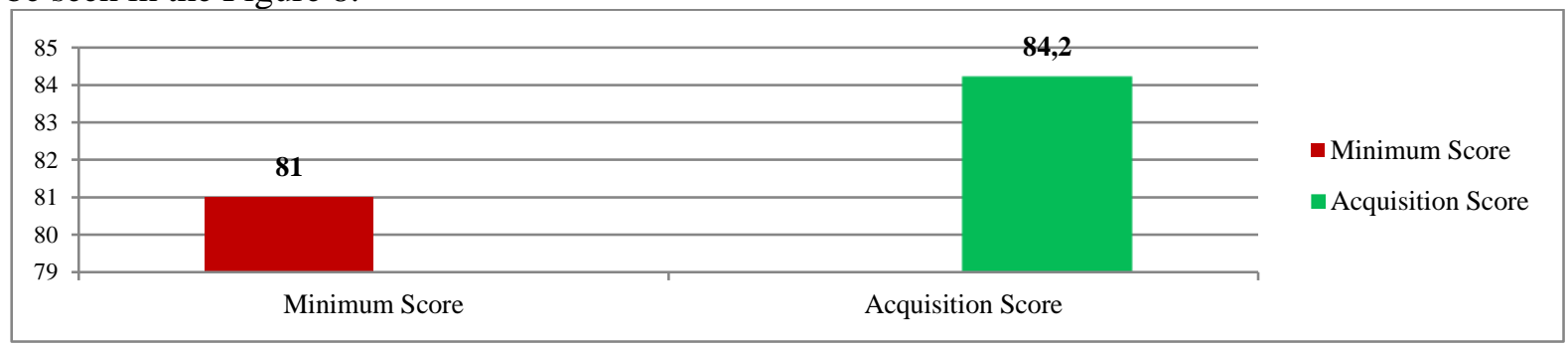

Figure 8. Results of Children's Response Scores in Small Group Trials

Based on the Figure 8, it can be seen that the child's response score has reached 84.2. This result has exceeded the minimum score of 81 . In this small group trial, the module can make children enthusiastic for learning, active in learning, make it easier to learn self-development material and be motivated to learn.

The field trials were conducted at SLB PGRI Sentolo and SLB Ma'arif Bantul on students with moderate category intellectual disabilities, amount to 15 children who had not yet been subject to individual trials and small group trials. In addition, there were also 3 teacher responses to support the results of the trials conducted. The Figure 9 related to the total score from the teacher response questionnaire, namely:

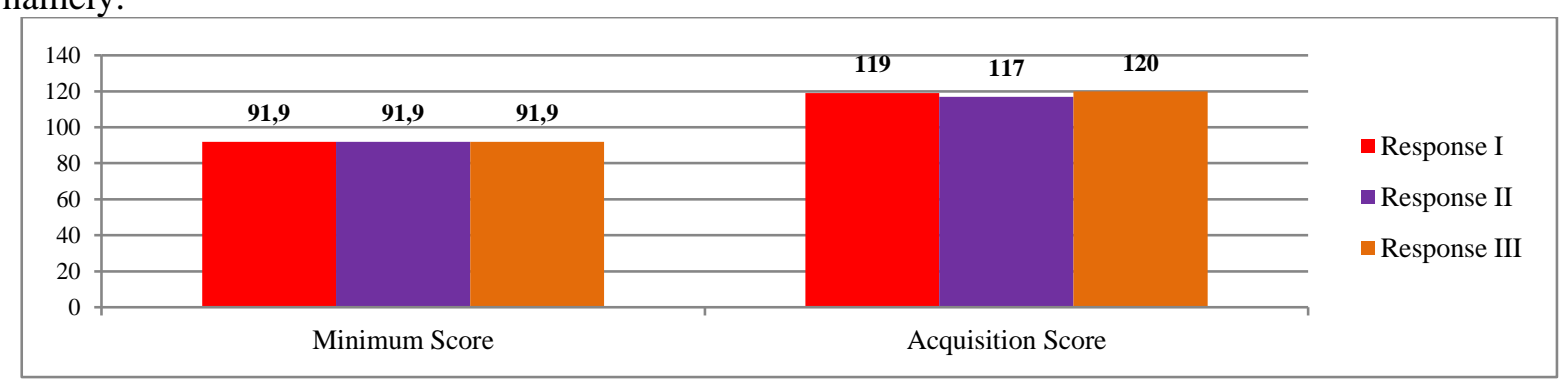

Figure 9. Results of Teacher Response Scores on Field Tests

Based on the Figure 9, it can be explained that the average total score of teacher responses in the field test to the activity of daily living module can be categorized as "very good". The teacher's response can exceed the minimum score of 91.9. From these results, the activity of daily living module is suitable to be used in self-development learning for students with moderate intellectual disabilities. Meanwhile, the results obtained from 15 children can be seen in the Figure 10. 
Jurnal Prima Edukasia, 9 (1), 2021 - 8

Noorita Dwi Sulistyaningrum, Mumpuniarti Mumpuniarti, Nurkhamid Nurkhamid

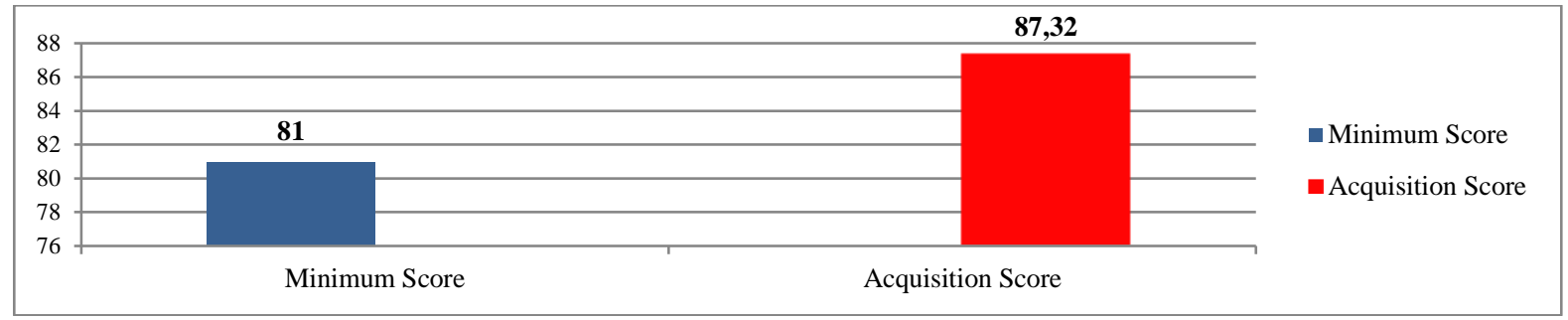

Figure 10. Results of Field Test Child Response Scores

Based on Figure 10, it can be seen that the child's response score has reached 87.32. This result has exceeded the minimum score of 81 . In the field test, the activity of daily living module can be used in self-development learning for children with moderate intellectual disabilities because the module can make children enthusiastic for learning, active in learning, make it easier to learn self-development material and motivated to learn because of positive reinforcement in modules such as giving stickers as a reward when the child succeeds in doing self-building activities.

The activity of daily living module developed consists of: (1) title page (Figure 11); (2) foreword (Figure 12); (3) introduction (Figure 13); (4) table of contents (Figure 14); (5) study instructions (Figure 15); (6) competencies and indicators (Figure 16); (7) Learning Activities I to VIII (Figure 17-21); (8) key answer (Figure 22); (9) bibliography (Figure 23). In the following, the module parts are developed:

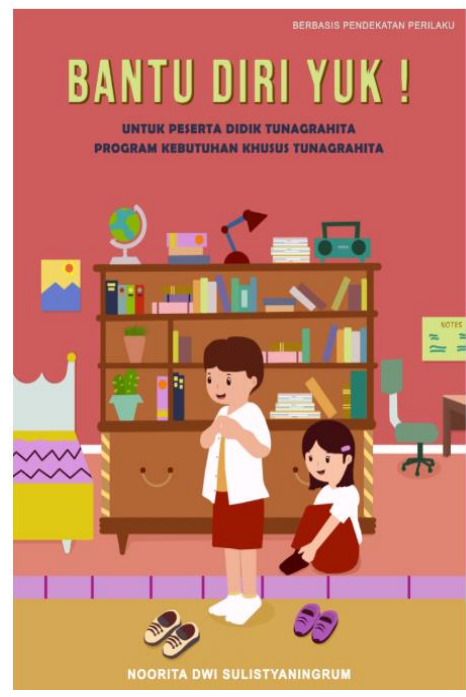

Front cover

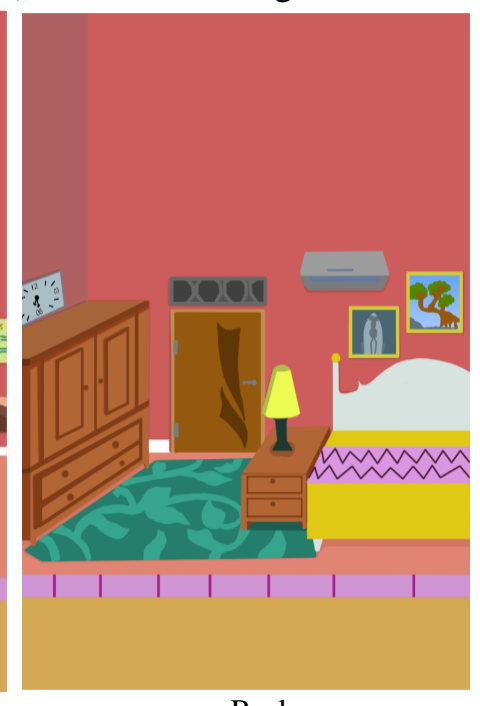

Back cover

Figure 11. Cover of Activity of Daily Living Module

The module has the same cover as the title page. The title of the module is "Help Yourself Come On!" completed with pictures of two children doing activities wearing clothes and shoes.

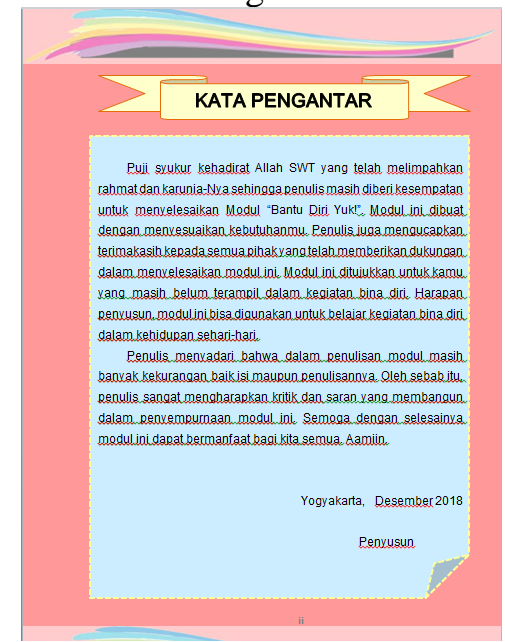

Figure 12. Foreword 
Jurnal Prima Edukasia, 9 (1), 2021 - 9

Noorita Dwi Sulistyaningrum, Mumpuniarti Mumpuniarti, Nurkhamid Nurkhamid

The foreword contains gratitude for the completion of the activity of daily living module, gratitude, the objectives and benefits of the module as well as constructive criticism and suggestions.

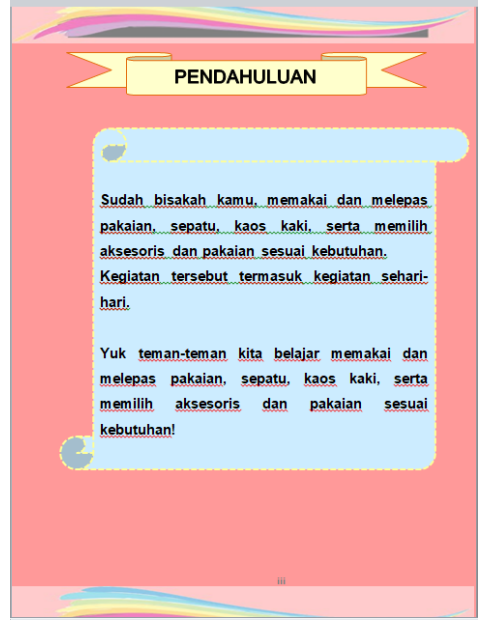

Figure 13. Introduction

This introduction contains the activities of daily living that will be studied in the module as well as an invitation to study these activities. The title is yellow and the introduction content is blue so that children can focus more on seeing the contents of the introduction.

The table of contents contains a list of learning activities in the module accompanied by pages. The basic color of the title and contents of the table of contents is made different so that children can focus when viewing the contents of the table of contents.

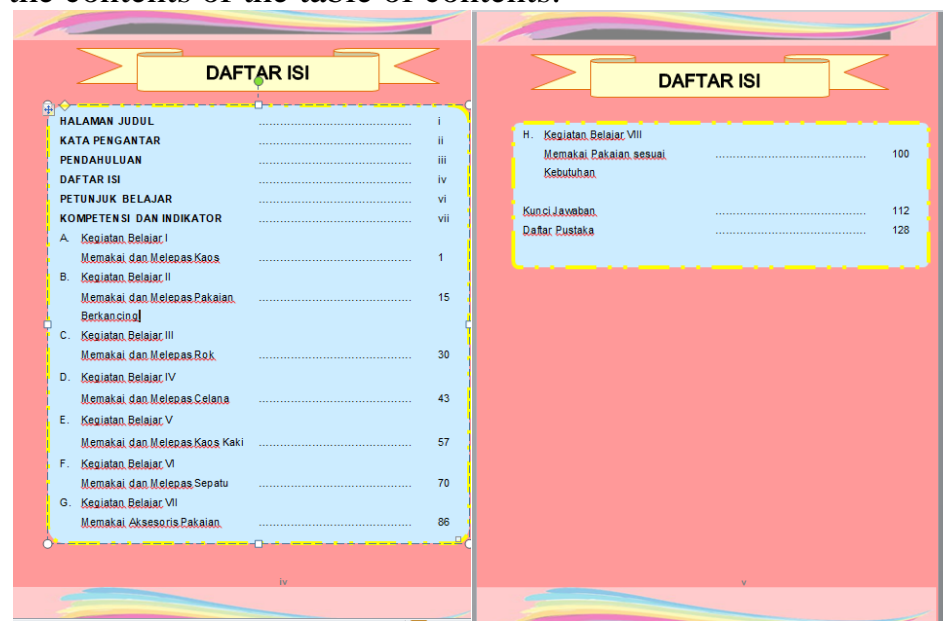

Figure 14. Table of Contents

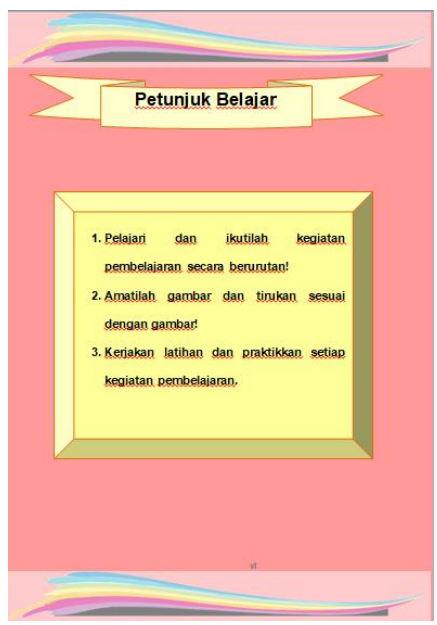

Figure 15. Study Instructions 
Jurnal Prima Edukasia, 9 (1), 2021 - 10

Noorita Dwi Sulistyaningrum, Mumpuniarti Mumpuniarti, Nurkhamid Nurkhamid

The study instructions contain how to learn using the activity of daily living module.

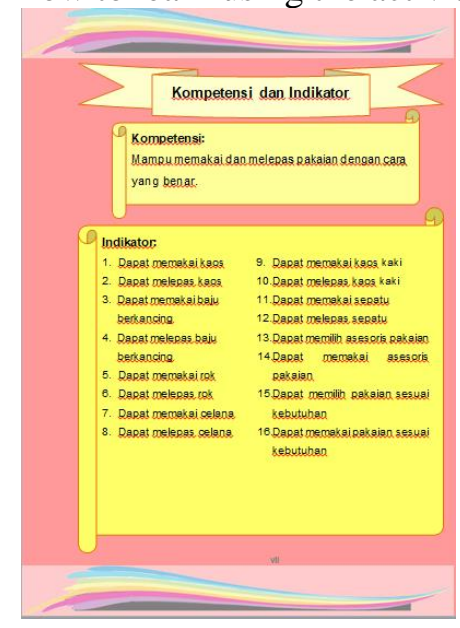

Figure 16. Competencies and indicators

Competence and indicators contain the competence of wearing and removing clothes and there are sixteen indicators.

Furthermore, learning activities include delivery of learning objectives, introduction of tools used for self-development activities, steps to carry out self-development activities, summaries, exercises, assessments, and positive reinforcement. Each of these sections is presented in Arial letters, with the font size of the subtitles 18 pts and the font size in the contents of the 15 pts. Every learning activity has a different background color, so that children are interested in seeing every learning activity and do not get bored easily when studying. There are 8 learning activities in the module.

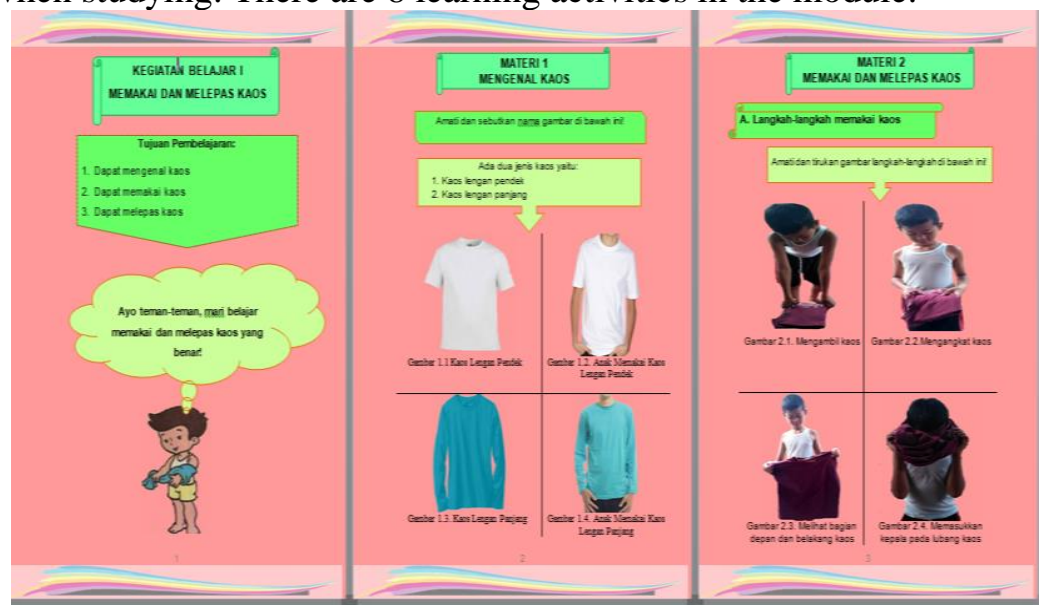

Figure 17. Presentation of Material in the Module

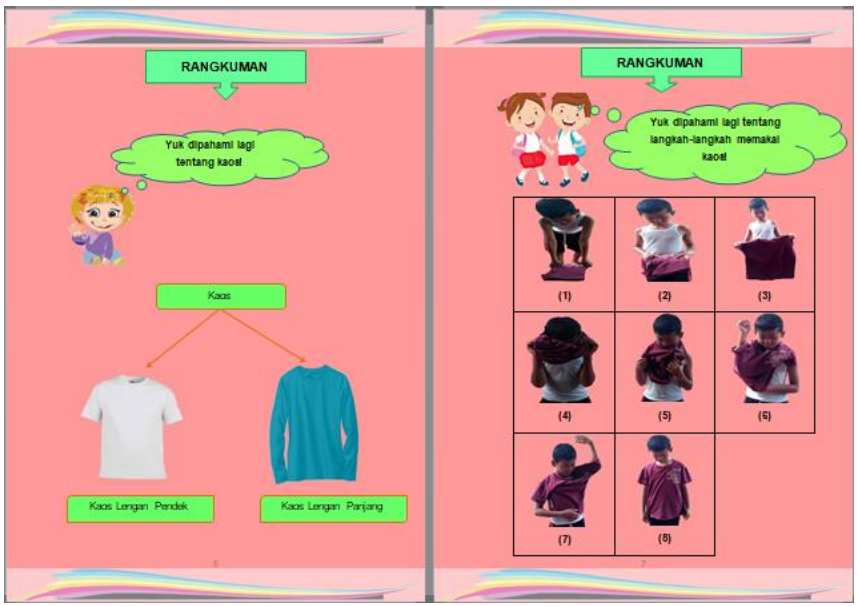

Figure 18. Presentation of Summary 
Jurnal Prima Edukasia, 9 (1), 2021 - 11

Noorita Dwi Sulistyaningrum, Mumpuniarti Mumpuniarti, Nurkhamid Nurkhamid

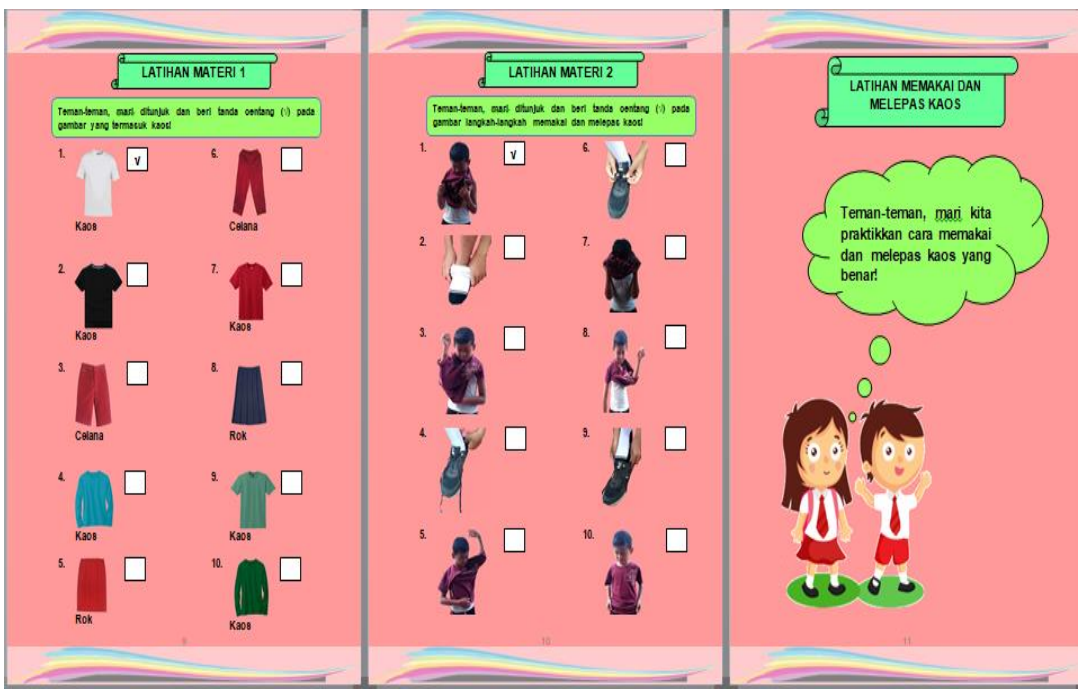

Figure 19. Presentation of Exercises in the Module

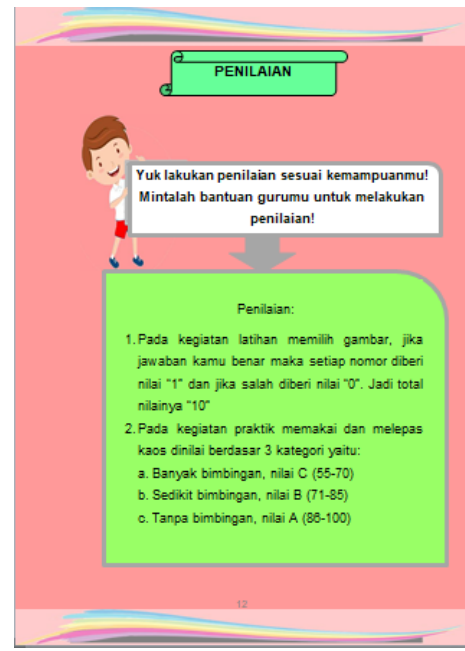

Figure 20. Assessment for exercise

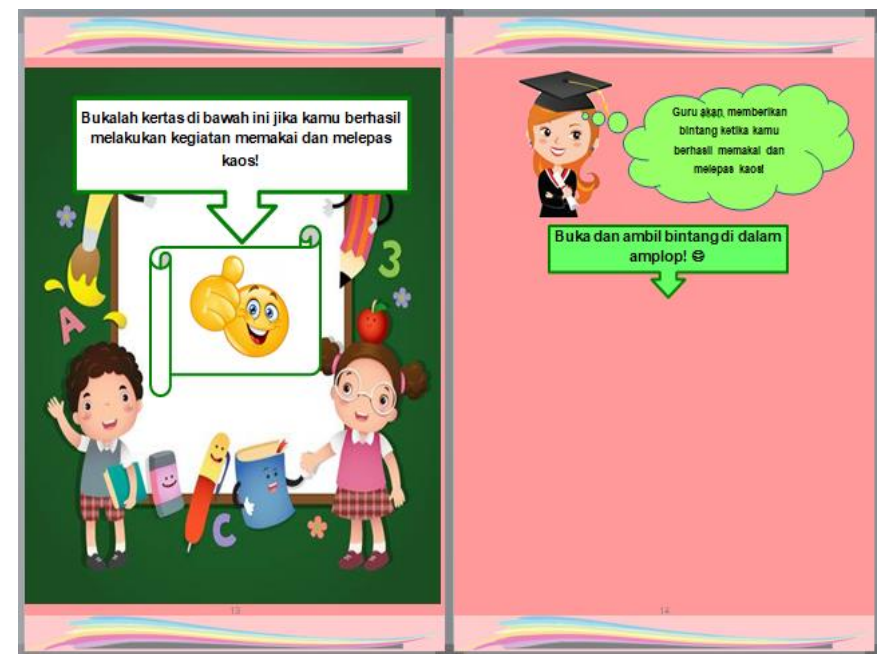

Figure 21. Positive Reinforcement/Positive Reinforcement to the Module 
Jurnal Prima Edukasia, 9 (1), 2021 - 12

Noorita Dwi Sulistyaningrum, Mumpuniarti Mumpuniarti, Nurkhamid Nurkhamid

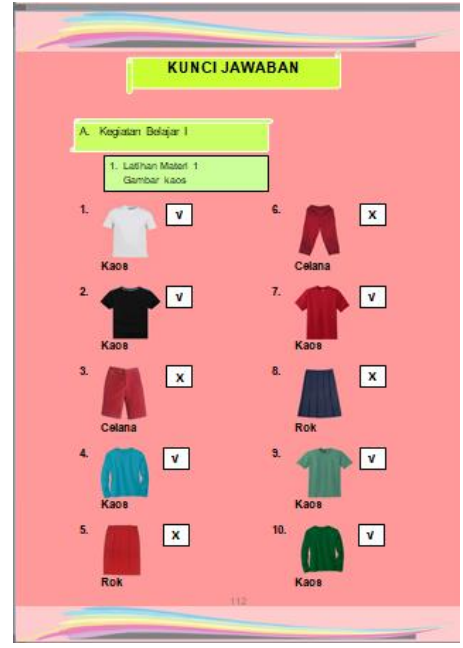

Figure 22. Key answer

In the module there is also a key answer which is the answer of the exercise. With the key answer in the module, children can correct themselves, the answer is right or wrong.

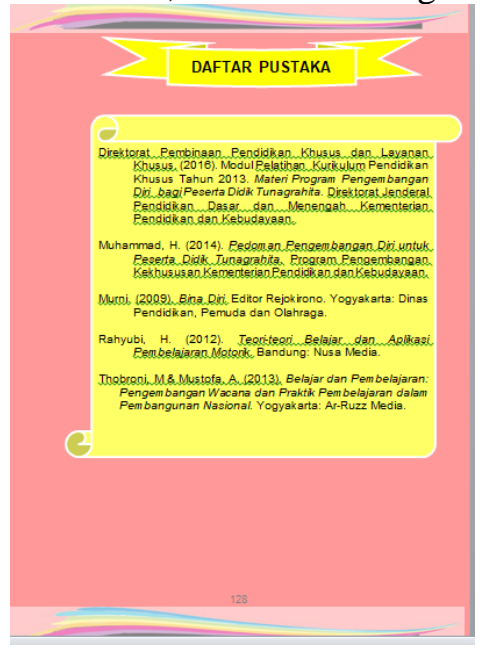

Figure 23. Bibliography

The bibliography compiled is a reference or a list of sources in taking competencies and indicators, implementing a behavioral approach and learning activities of daily living.

The products developed above are customized o the characteristics of children with moderate intellectual disabilities so that the presentation of the material is more pictures and is presented in a simple way. The parts of the module shown above are also an outline and one example of the material in the module because in the module there are eight materials on wearing and taking off clothes that can be learned by children with moderate intellectual disabilities. However, by presenting each material, the exercises and positive reinforcement are the same as the first material.

This ADL module is prepared as a form of service support in functional academics for children with intellectual disabilities. This is in line with what Hallahan et al. (2018) stated, regarding children with moderate intellectual disabilities who need special services in both functional and non-academic fields. Based on research Lussier-Desrochers et al. $(2014$, p. 16) that intellectual disabilities requires a thorough understanding of individuals' needs and skills related to the accomplishment of their daily living activities. The existence of a module that contains self-development can be used as a guide in providing learning how to dress themselves so that children can perform clothing activities in the correct order or steps according to the results of research conducted by Dewi et al. (2017, p. 52). Dressing up is a simple activity but it is done every day so it is important for children with intellectual disabilities to master it. The existence of this module can also be used as a medium of learning when learning to dress up. 
During the trial, learning activities using the ADL module still require supervision and guidance from the teacher because of limited abstract thinking in children with intellectual disabilities. This is in accordance with what Baroff and Olley (2014) stated, regarding self-development activities related to basic self-care which always require some level of supervision. The ADL module that was developed can help children learn self-development activities so that eventually children can have independence. This is in accordance with what was expressed by Bilqis (2014, p. 35) and Sudarsini (2019), regarding the function of self-development activities.

Daily activities for children with intellectual disabilities are the main focus in providing educational services. The development of this module on clothing self-development includes activities of daily living as expressed by Albert (2014, p. 93) and Steinmetz (2013, p. 218) about dressing which includes daily activities. Therefore, this dressed self was chosen for the material in the module being developed. In the developed module, there are practical exercises for self-development in dress and presentation of material in the form of conducting dress activities in order and correctly. This is because children with intellectual disabilities will be quickly master self-building skills with continuous training. The results of research by Adnyani et al. (2015) also state that there is an effect of the training method or drill on the ability of children with moderate intellectual disabilities.

The module developed is also based on a behavioral approach. The behavioral approach in the module includes objectives and materials made from simple to complex, the material is presented in the form of task analysis, positive verbal reinforcement presented in the form of lift the flap and rewards in the form of star stickers. This application is in accordance with the opinion of Schunk (2012) and Thobroni (2011), regarding the principles of a behavioral approach. The behavioral approach in the module can also motivate and increase student activity when learning to dress by themselves. This is consistent with what (Adi, 2013, p. 29; Boesch et al., 2015; Stark et al., 2012), on a behavioral approach can help change student behavior that is less appropriate. Therefore, it is appropriate if it is applied to students with intellectual disabilities who experience many problems in learning, especially related to student motivation and activeness such as the results of research by Adisty et al. (2014, p. 164).

Children with moderate category of intellectual disabilities have a lot of difficulties in their daily activities. Research by Cornoldi et al. (2014), states that children with intellectual disabilities have general intellectual disabilities than children with specific learning disorders. This general intellectual disorder will have an impact on his daily activities. Therefore, the development of this module will be of great benefit to children. This, as well as the results of research by Schoufour et al. (2014, p. 94) on the index of weakness which is significantly related to disabilities in daily functions. In children with intellectual disabilities, in minimizing weaknesses in daily activities, it is necessary to be given training from childhood. Independence is an important aspect for them. Research by Shepley et al. (2018, pp. 10-11) reveals that independence can be trained in academic, social, daily life, and vocational skills for intellectual disabilities. Independence in wearing and undressing for moderate intellectual disabilities is part of daily life. The results of research by Luckasson et al. (2017, p. 273) state that prevention activities for intellectual disabilities cannot reduce the disturbance that occurs, but what can be done is to try to optimize independence and improve quality of life. Therefore, the self-development module for wearing and removing clothes was chosen as one of the self-reliance programs that must be taught.

In trials conducted on children with intellectual disabilities, it shows that children have increased their ability to do self-grooming when compared to before learning to use modules. Children are also more motivated and enthusiastic about learning using the ADL module. The results of the research which show that there is an increase and high motivation in self-development learning activities are also in line with research conducted by Ingwarni (2018) and Setyorini and Izzaty (2016) regarding significant differrences in students who use modules. learning and students who do not use the learning module. In addition, it is also based on the research results of Cannella-Malone et al. (2013, p. 188), that the existence of teaching tools can be effective for students with intellectual disabilities in learning daily skills. Therefore, the existence of a module that can be used as a learning medium can be effectively used by students to learn to develop themselves in wearing and taking off clothes.

\section{Conclusion}

Based on the results of validation and field trials, the activity of daily living module based on the behavioral approach can be declared feasible for use both in terms of material and media. The activity 
of daily living module consists of: (1) title page, (2) foreword, (3) introduction, (4) table of contents, (5) study instructions, (6) competencies and indicators, (7) Learning Activities I to VIII, (8) key answer, (9) bibliography. Each learning activity is also equipped with a positive assessment and reinforcement in the form of verbal and rewarding in the form of star stickers. Modules are arranged based on the condition of moderate category students with intellectual disabilities so that their presentation in the form of pictures and attractiveness will make it easier for students to learn. The behavioral approach in the module such as positive reinforcement will also make students enthusiastic and excited for learning. Thus, it can be concluded that the activity of daily living module based on the behavioral approach in the special program for children with moderate intellectual disabilities category is feasible to use.

\section{References}

Adi, K. J. (2013). Esensial konseling: Pendekatan trait and factor dan client centered. Garudhawaca.

Adisty, N. C. P., Hastuti, W. D., \& Kustiawan, U. (2014). Peningkatan kemampuan praktik bina diri dengan menggunakan media boneka model manusia untuk siswa tunagrahita ringan SDLB. Jurnal Penelitian Dan Pengembangan Pendidikan Luar Biasa, 1(2), 163-168. http://journal2.um.ac.id/index.php/jppplb/article/view/4319

Adnyani, D. N. N., Suarni, N. K., \& Jampel, I. N. (2015). Pengaruh metode drill terhadap motivasi belajar dan kemampuan merawat diri sendiri bagi anak tunagrahita pada pelajaran bina diri siswa kelas I SLB. C1 Negeri Denpasar tahun pelajaran 2014/2015. Jurnal Penelitian Dan Evaluasi Pendidikan Indonesia, 5(1).

Albert, S. M. (2014). Public health and aging: An introduction to maximizing function and well-being. Springer Publishing Company.

Baroff, G. S., \& Olley, J. G. (2014). Mental retardation: Nature, cause, and management. Routledge.

Bilqis, B. (2014). Lebih dekat dengan anak tunadaksa: Relasi inti media. Diandra Kreatif.

Boesch, M. C., Taber-Doughty, T., Wendt, O., \& Smalts, S. S. (2015). Using a behavioral approach to decrease self-injurious behavior in an adolescent with severe autism: A data-based case study. Education and Treatment of Children, 38(3), 305-328. https://doi.org/10.1353/etc.2015.0012

Cannella-Malone, H. I., Brooks, D. G., \& Tullis, C. A. (2013). Using self-directed video prompting to teach students with intellectual disabilities. Journal of Behavioral Education, 22(3), 169-189. https://doi.org/10.1007/s10864-013-9175-3

Cornoldi, C., Giofrè, D., Orsini, A., \& Pezzuti, L. (2014). Differences in the intellectual profile of children with intellectual vs. learning disability. Research in Developmental Disabilities, 35(9), 2224-2230. https://doi.org/10.1016/j.ridd.2014.05.013

Dewi, W. N., Gunarhadi, G., \& Wagimin, W. (2017). Self-development learning in increasing activity of daily living in children with mild mental disability. European Journal of Special Education Research, 2(3). https://doi.org/10.46827/ejse.v0i0.500

Diaz, K. M. (2020). Physical activity and sedentary behavior among U.S. children with and without down syndrome: The national survey of children's health. American Journal on Intellectual and Developmental Disabilities, 125(3), 230-242. https://doi.org/10.1352/1944-7558-125.3.230

Dick, W., Carey, L., \& Carey, J. O. (2015). The systematic design of instruction (8th ed.). Pearson.

Garrels, V. (2017). Goal setting and planning for Norwegian students with and without intellectual disabilities: Wishing upon a star? European Journal of Special Needs Education, 32(4), 493507. https://doi.org/10.1080/08856257.2016.1261487

Hallahan, D. P., Kauffman, J. M., \& Pullen, P. C. (2018). Exceptional learners: Introduction to special education (9th ed.). Pearson Education.

Harris, J. C. (2010). Intellectual disability: A guide for families and professionals. Oxford University Press.

Ingwarni, S. (2018). Developing the socioculture-based thematic-integrative learning module for improving the learning motivation and the critical thinking. Jurnal Prima Edukasia, 6(2), 157165. https://doi.org/10.21831/jpe.v6i2.9447

Luckasson, R., Ford, M. E., McMillan, E. D., Misilo, F. M., \& Nygren, M. A. (2017). Intellectual 
Jurnal Prima Edukasia, 9 (1), 2021 - 15

Noorita Dwi Sulistyaningrum, Mumpuniarti Mumpuniarti, Nurkhamid Nurkhamid

disability policy as developed, expressed, and evaluated in AAIDD/The arc joint statements:

The role of organization position statements. Intellectual and Developmental Disabilities, 55(4), 269-275. https://doi.org/10.1352/1934-9556-55.4.269

Lussier-Desrochers, D., Lachapelle, Y., \& Caouette, M. (2014). Challenges in the completion of daily living activities in residential settings. Journal on Developmental Disabilities, 20(1), 16. https://oadd.org/wp-content/uploads/2014/01/41017_JoDD_20-1_v11f_16-24_LussierDesrochers_et_al.pdf

Schoufour, J. D., Mitnitski, A., Rockwood, K., Hilgenkamp, T. I. M., Evenhuis, H. M., \& Echteld, M. A. (2014). Predicting disabilities in daily functioning in older people with intellectual disabilities using a frailty index. Research in Developmental Disabilities, 35(10), 2267-2277. https://doi.org/10.1016/j.ridd.2014.05.022

Schunk, D. H. (2012). Learning theories: An educational perspective. Pearson.

Setyorini, D., \& Izzaty, R. E. (2016). Pengembangan perangkat pembelajaran untuk meningkatkan motivasi belajar dan karakter bersahabat siswa kelas IV SD. Jurnal Prima Edukasia, 4(2), 120. https://doi.org/10.21831/jpe.v4i2.8215

Shepley, S. B., Spriggs, A. D., Samudre, M., \& Elliot, M. (2018). Increasing daily living independence using video activity schedules in middle school students with intellectual disability. Journal of Special Education Technology, 33(2), 71-82. https://doi.org/10.1177/0162643417732294

Stark, J. A., Menolascino, F. J., Albarelli, M. H., \& Gray, V. C. (2012). Mental retardation and mental health: Classification, diagnosis, treatment, services. Springer Science \& Business Media.

Steinmetz, S. K. (2013). Family and support systems across the life span. Springer Science \& Business Media.

Sudarsini, S. (2019). Fisioterapi. Gunung Samudera.

Sugiyono. (2010). Metode penelitian kuantitatif kualitatif dan $R \& D$. Alfabeta.

Thobroni, M. (2011). Belajar \& pembelajaran: Pengembangan wacana dan praktik pembelajaran dalam pembangunan nasional. Ar-Ruzz Media.

Udonwa, R. E., Iyam, M. A., Osuchukwu, N. C., Ofem, O., Etim, J. J., \& Ikong, M. A. (2015). Mentally retarded children and deficits in daily living skills: Case study of Calabar municipality local government area, Cross River state, Nigeria. Journal of Research \& Method in Education, 5(2), 21-26. https://doi.org/10.9790/7388-05232126 